\title{
The Palazzo, Collections, and Musical Patronage of Niccolò Gaddi (1536-91)
}

Laura Moretti

This article examines the collection of musical instruments and music books (both published editions and manuscripts) belonging to the Florentine Niccolò di Sinibaldo Gaddi. One of the greatest collectors and patrons of the arts of his time, in the 1570s and 1580s he organized and fit out one of the largest private collections of the era in the so-called casa dell'orto. Today it is possible to reconstruct not only the scope of his collections but also the breadth of his incredibly rich library thanks to an unpublished inventory from 1628 and analyses of other primary sources. Around forty musical instruments and a group of one hundred and thirty volumes of printed and manuscript music books were among the thousands of objects exhibited. The identification of several of them has made it possible to advance new hypotheses on the contributions made to the collection by various members of the family.

Niccolò di Sinibaldo Gaddi was one of the greatest collectors and patrons of the arts in Florence in the second half of the sixteenth century (Fig. 1). ${ }^{1}$ He was the last descendent of a family that had played a leading role in the political, religious and cultural life of the city for over four centuries, and was able to boast among its members the painters Gaddo (c.1239-c.1312), Taddeo (c.1290-1366) and Agnolo (c.1350-96), the secretary of the Florentine Republic, Francesco (1441-1504), and the cardinals Niccolò (1490-1552), Giovanni (1493-1542), Taddeo (1520-61) and Girolamo (c.1520-71). ${ }^{2}$

It was in the so-called casa dell'orto, located on Piazza Madonna degli Aldobrandini between the Churches of San Lorenzo and Santa Maria Novella, that in the 1570s and '80s, Niccolò Gaddi arranged his notable collection of works of art, musical and scientific instruments, manuscripts and books, drawings and prints, naturalia, coins and medals, tiny objects and curiosities of all sorts, derived in part from his family legacy, and in part from his own huge additions to it. ${ }^{3}$ Thanks to some documents of 
the period, and above all to inventories and archival documents, it is possible today to reconstruct the scope and substance of the collections. ${ }^{4}$

Research of the past forty years has shed light above all on Gaddi the collector of works of art and his interests, particularly in the field of architecture. Such studies have focussed on his collections of drawings and prints - which encompassed, among other things, several volumes of Giorgio Vasari's Libro de' disegni - and on his architectural commissions to artists such as Giovanni Antonio Dosio (1533-1611). ${ }^{5}$ Historical research reveals that Niccolò Gaddi was held in high esteem by Francesco and Ferdinando de' Medici. He served in fact as a consultant on art and antiquity for both patrons. Moreover, in September 1588 Ferdinando placed him in charge of planning the apparatus and overseeing the festivities for the arrival of Christina of Lorraine in Florence, whom he eventually married. ${ }^{6}$

This article will nevertheless tackle, for the first time in detail, Niccolò Gaddi's interest in music. An inventory of the casa dell'orto compiled in 1591 reveals in fact that at that time the building held a collection of around forty instruments and 130 volumes of printed and manuscript musical partbooks. These objects, along with many others, were arranged in rooms that followed a course of what could be termed a 'proto-museum', and inside of which musical performances may have taken place. ${ }^{7}$ Analysis of another hitherto unpublished inventory drawn up in 1628 along with a reading of several later documents now make it possible to advance new hypotheses regarding the contents and provenance particularly of the printed editions, and to shed more light on Niccolò Gaddi's musical patronage and interests.

\section{Musical instruments, as well as printed and manuscript music books in the documents of 1591}


In an inventory of the casa dell'orto drawn up on 24 November $1591,{ }^{8}$ after the demise of its owner Niccolò di Sinibaldo Gaddi on 14 June of that year, around forty musical instruments are listed as being in a room on the ground floor, referred to as the stanza de'suoni: ten viols, six lutes, one lyre, one harp, two citterns, two pandouras, one clavichord, one harpsichord, six trombones in their cases, seven flutes in a case, and a cornet. ${ }^{9}$ In addition to these, the document reports the presence of an 'unfinished' 'wooden organ' in another ground-floor space called galleria.${ }^{10}$ This was a case of a rich collection that included wind, string, keyboard and plucked instruments. Running down the long and detailed inventory, we discover that the building's first floor accommodated a library with a total of 1400 manuscripts and printed editions, among which were 'one hundred and thirty containing music of all sorts'. ${ }^{11}$ What is important to stress here is the impossibility of determining with certainty, on the basis of the available data, whether the instruments and music books, either printed or manuscript, listed in the inventory of 1591 were acquired by Niccolò Gaddi or by his predecessors; all the same - as we shall see below - it is possible to propose several hypotheses.

From what is currently known, at least one of Niccolò's paternal uncles, Cardinal Giovanni Gaddi (1493-1542), was a patron of music and musicians. ${ }^{12}$ For a long time he resided in Rome, where he distinguished himself for his patronage of the arts, commissioning a sumptuous palazzo from Jacopo Sansovino and organizing events that were recalled, among others, by Giorgio Vasari. ${ }^{13}$ He also owned a well-stocked library. ${ }^{14}$ The possibility that another one of Niccolò's paternal uncles, likewise named Niccolò (1492-1552), ${ }^{15}$ had an interest in music and was a patron of musicians has already been proposed. ${ }^{16}$ What is definitely known, however, is that thw collection of sculptures and paintings had begun with the illustrious forebears, the 
first of whom was Agnolo di Taddeo Gaddi (c.1350-96), and had been housed for a long time in the family palazzo (also know as the casa grande or casa degli sporti), situated in the Piazza Madonna degli Aldobrandini. ${ }^{17}$ The objects were kept in this fourteenth-century house until the second half of the 1570s, when Niccolò purchased some new properties and moved his collection to the casa dell'orto, which he restored and reconfigured for this purpose (Fig. 2). ${ }^{18}$

A few further details on some of the musical instruments can be gleaned from Gaddi's own will, compiled on 9 June $1591,{ }^{19}$ in which three of them are specifically mentioned. First, is the expressed desire to have the wooden organ in the galleria finished according to the design of a certain 'Lorenzo di Domenico carpenter', who was building it together with an artisan called 'Annibale da Milano'. The latter is identifiable with Ferrante de' Rossi (fl. 1580-97), son and follower of Annibale (de' Rossi) da Milano (fl. 1542-77), renowned harpsichord and organ maker who died well before 1591 . Ferrante at the beginning of the 1590 s was probably still working under his father's name, a deferential and well-documented practice in those days among craftsmen. ${ }^{20}$ Next is an arrangement to leave the harpsichord 'covered in a green cloth' to Gaddi's second wife, Maria di Alfonso Strozzi, ${ }^{21}$ who had married him after the death of his first one, Emilia di Lorenzo Ridolfi, in $1563 .^{22}$ The 'new harpsichord being made', which was to be completed by the heirs, ${ }^{23}$ was meant for Piero di Matteo Strozzi (1551-1614), a musician, amateur composer, and distant relative of the second wife. ${ }^{24}$ This last instrument must have been removed at the moment of Niccolò's death since it does not appear among the list of his possessions in the inventory compiled just a few months later.

In order to gain deeper understanding of Gaddi's interest in music, we must consider the building and various spaces in which the objects mentioned in the 1591 
documents were placed according to his desire. This will enable us to put forward hypotheses regarding possible musical performances organized in them.

\section{Music in the casa dell'orto}

The Gaddi family possessed various properties in the area around Piazza Madonna degli Aldobrandini, among which was the so-called casa grande or casa degli sporti, built in the fourteenth century by the sons of the painter Taddeo (c.1290-1366), and progressively enlarged by his heirs (Fig. 2, letter A) ${ }^{25}$ Niccolò came into possession of the house with the death of his father, Sinibaldo di Taddeo (1499-1558), and afterwards commissioned the architect Giovan Antonio Dosio to carry out a general reconstruction, which was probably completed, at least in part, between 1585 and 1590. ${ }^{26}$ Meanwhile (in 1573 to be precise) Niccolò acquired an adjacent property, on which a small structure already stood. ${ }^{27}$ It was here, on this new property, which included a garden, ${ }^{28}$ that in the following years the same Dosio undertook a project to restructure and expand what would later come to be known as the casa dell'orto (Fig. 2, letter B). Between 1575 and 1576 Dosio also worked on the family chapel in the nearby Church of Santa Maria Novella, once again on commission from Niccolò Gaddi. $^{29}$

From the moment of its conception, the casa dell'orto was intended to be a building reserved exclusively for the display of Gaddi's collection: works of art, drawings and prints, manuscripts and printed books, naturalia and tiny objects, coins and medals, mathematical and musical instruments. The collections were distributed according to type in various rooms, arranged on two levels. Within this circuit, particular attention was paid to the elements of display: custom-made supports ('large stools with the 
arms of the Gaddi, ${ }^{30}$ frames, shelves and other furniture items) were used to exhibit the various objects.

Niccolò intended that the casa dell'orto and the collections it housed be accessible to the public. Indeed, in his will he affirmed that: 'I wish that the things that will be in the casa dell'orto be shown by my heirs with care and courtesy to all Florentine and foreign gentlemen who would like to see them'. ${ }^{31}$ We can assume that Gaddi had in mind a select, refined and cultured audience, possibly members of the nobility, who might have access to the palazzo on request, but by invitation, and under the watchful eye of the owner or of a delegate.

Scipione Ammirato described the palazzo and collections in a letter to Ferdinando de' Medici:

In the City, twenty arms' length from his residence, [Niccolò Gaddi] has another house with a garden, the kinds of places owned by important Citizens for their pleasure and known as Casini. In the Garden there are the most excellent and rarest medicinal herbs [...]. On one side of the said garden is a gallery of several arms' length, along each side of which stand the most noble statues in marble atop pedestals, and above these statues are paintings by good masters [...] when conducted through the upper-floor apartments I became utterly confused as I reflected upon what the love, assiduity, and genius of man could achieve [...] it will suffice to say that this is a hall with two rooms, two studiolos with tiny additional studiolos, and with a ceiling full of ornaments in marble, bronze casts, paintings, with so many repositories of the rarest sorts of ancient things, arms, measures, weights, and other oddities. ${ }^{32}$

As Ammirato emphasizes, this was a non-residential building, of a type also named back then casino. ${ }^{33}$

According to the 1591 inventory, the galleria contained paintings and sculptures in addition to the aforementioned unfinished wooden organ. ${ }^{34}$ Specifically, it housed around twenty marble busts and ten or so statues of various size, around twenty paintings, of which nine were portraits, and some pieces of furniture (two benches, two stools, and two small tables). ${ }^{35}$ The wooden organ was placed, according to the document, at the 'head' of the hall, presumably, that is, along the wall opposite the 
entrance. ${ }^{36}$ Numerous other rooms contained works of art and collections of various kind. The library, which also held the collection of printed and manuscript music books, was on the second level, over the galleria. ${ }^{37}$ The so-called stanza de' suoni, situated on the ground floor, contained nothing but musical instruments and some cases to keep them in. ${ }^{38}$

Andrew Morrogh discovered and recently published several drawings from the Gabinetto dei Disegni e Stampe at the Uffizi, among which, in particular, were two ground plans and a few elevations that he attributed to Giovan Antonio Dosio, believed to be related to the casa dell'orto (Figs 3-4). ${ }^{39}$ By comparing one of these, GDSU, 623 A (Fig. 3) - a drawing of a ground plan - to the 1591 inventory, we may note a nearly total correspondence. Indeed it is possible to follow the sequence of rooms listed in the inventory step by step: andito della casa piccola, ('vestibule of the little house', marked as n.1 on the drawing), scrittoio a terreno ('tiny study on the ground floor', n. 2), camera terrena che riesce in su la strada ('ground-floor room that leads up to the street', n. 3), andito che riesce in su la loggia ('passageway that leads to the loggia', n. 4), loggetta sull'orto ('little loggia over the garden', n. 5), camera in su l'orto ('room towards the garden', n. 6), spezieria ('laboratory for medicinal herbs', n. 7), stanza de' suoni ('musical instrument room', n. 8), corticina ('little courtyard', n. 9), orto ('garden', n. 10), galleria su l'orto ('gallery over the garden', n. 11). We can therefore assume that the drawing shows Dosio's plan as it was completed. The sole significant discrepancy between it and the 1591 inventory involves the galleria: the dividing walls of the long vaulted space delineated in the drawing do not seem to have been built. Created instead was an ample, seamless, space, which was developed particularly lengthwise. ${ }^{40}$ 
What is important to emphasize here, in view of what was noted above, is the proximity of the stanza de' suoni (n. 8), which housed the collection of musical instruments, to the galleria su l'orto (n. 11), which, we may recall, contained the wooden organ in addition to a huge number of works of art. Given the relative dimensions of the stanza de' suoni, which appear quite small in the drawing, we can assume that this was a space dedicated exclusively to holding and displaying instruments, and that musical performances may have been organized in the galleria and perhaps also in the loggetta (n. 5) or in the open, in the orto (n. 10). Although musical performances in the open or in loggias overlooking the gardens of villas and palazzi are often recorded in literary and iconographical sources - a perfect example, albeit in a different context, being the so-called Concerto in villa by Pozzoserrato, now at the Museo Civico, Treviso ${ }^{41}$ - cases of rooms devoted specifically to the display of musical instruments (save a few on the premises of Italian Renaissance courts), or of musical instruments placed in rooms reserved primarily for the exhibition of paintings and sculptures are nearly absent in sources from this period. ${ }^{42}$ In this sense, Niccolò Gaddi's casa dell'orto is an extremely important example, not only for its collections and organization of art objects, but also, among various other things, for its assemblage and utilization of musical instruments.

Complex issues of inheritance led to swift changes in the features of the building and its contents, which to some degree altered what had been achieved in the late sixteenth century. Niccolò Gaddi died without leaving any direct heirs. At first, however, as his will establishes, the casa dell'orto passed down to his nephew Luigi di Agnolo Gaddi (d. 1609), and afterwards to Camillo di Jacopo Pitti, another nephew, son of Niccolò's sister Maddalena, who had married Jacopo di Francesco Pitti. ${ }^{43}$ Niccolò's will expressly stipulated that Camillo abandon his own surname and 
assume 'the name of the Gaddi family and use it in public and in private', and that all subsequent heirs do likewise. ${ }^{44}$ This provision transmitted the name of this branch of the family to later generations even though it had died out with Niccolò. The 1591 will also suggested that if the next in line wished to make the building habitable, they could construct new quarters over the galleria dell'orto, to which they could move the collections in order to free up other rooms. ${ }^{45}$ And this is precisely what came to pass, as later documents testify.

\section{Musical instruments and printed music books in an unpublished inventory of} 1628

Preseved in the Archivio di Stato in Florence is an inventory of Camillo Pitti Gaddi's possessions dated to 11 February $1628 .{ }^{46}$ This is a hefty, fairly detailed document, from which it is possible to draw new information on the instruments and published music books belonging to Niccolò di Sinibaldo Gaddi. ${ }^{47}$

The harpsichord that he had bequeathed to his wife, mentioned in the 1591 documents, was now in a room on the first floor of the casa dell'orto. ${ }^{48}$ Maria di Alfonso Strozzi long outlived her husband and resided in the building, as is testified, in fact, by the 1628 inventory.

The other musical instruments were clearly moved to the first floor of the gallery's wing, just as Gaddi had proposed in his 1591 will. The 'second room of the galleria' in fact, housed a clavichord, six lutes, three citterns, two 'Spanish guitars', a 'little lute', six trombones, a 'black bone flute with a silver sleeve', 1 violin, a 'suono', and 11 'ralini' ${ }^{49}$ The latter remains an unknown word, possibly a fault of the inventory's compiler, which I would interpret as 'viols'. It seems in fact that the inventory was written by someone rather incompetent in musical instruments' terminology. Also the 
meaning of the word 'suono' remains uncertain (and for this reason not translated here).

Essentially, although there are still some uncertainties due to the terms used by the compiler of the inventory, this was the same group of objects listed four decades earlier. A box with thirty-five reels of string could likewise be found in this room. This detail allows us to infer that the instruments were being played for a while or at least that this was Gaddi's or his nephews' intention, and that they were thus not simply objects of display. The document makes instead no reference to the wooden organ that Niccolò Gaddi had wanted his nephews to bring to completion.

In the inventory of 1628 all printed volumes preserved in the libreria della galleria are listed one by one. ${ }^{50}$ Running down the densely written, forty double-sided pages of this list, in which both author and subjects are alphabetically organized, we can single out the titles of editions ofprinted music. Since the descriptions are rather generic, it is not always possible to identify them:

$[\ldots][92 \mathrm{v}][\ldots]$

- Arcadele Madrigali à Quattro ${ }^{51}$

- Adriano Vigliar Ricercari ${ }^{52}$

- Agostino Vicino Dierimatici, à due voci ${ }^{53}$

- Adriano Vigliar Mottetti à Quattro ${ }^{54}$

- Arcadel Madrigali à Quattro 55

[93r]

- Il medesimo Fiore de Madrigali ${ }^{56}$

- Il medesimo secondo libro de Madrigali à Quattro ${ }^{57}$

- Animuccia Madrigali à quattro, cinque e sei ${ }^{58}$

- Alessandro Strigio, giuoco di Primiera in Musica ${ }^{59}$

- Anton Francesco Doni Dialogo della Musica ${ }^{60}$

- Alessandro Strigio Madrigali à cinque e à sei ${ }^{61}$

- Armonia à Sei voci di diversi ${ }^{62}$

[...] [96v] [...]

- Brunello messe in Musica ${ }^{63}$

- Baldassarre Donato Madrigali à $567^{64}$

$[\ldots][97 \mathrm{r}][\ldots]$

- Bernardino Lupacchino 65

[...] [100r] [...]

- Cipriano Rorje Madrigali à Quattro ${ }^{66}$ 
- Il medesimo Madrigali à cinque ${ }^{67}$

- Costanzo Festa Madrigali à tre con diversi autori ${ }^{68}$

- Cipriano Rorje Fantasie in Musica ${ }^{69}$

$[\ldots][104 \mathrm{v}][\ldots]$

- Enrico Scappen Madrigali à Quattro ${ }^{70}$

$[\ldots][107 r][\ldots]$

- Fenimme Messe in Musica ${ }^{71}$

- Francesco Corteccia Responsi Settimana Santa in Musica ${ }^{72}$

- Franchino Giapporo Pratica della Musica Latina ${ }^{73}$

- Francesco Rossello Madrigali à Quattro ${ }^{74}$

- Filippo di Monte Madrigali à Sei ${ }^{75}$

- Francesco Portinaro Madrigali à Cinque ${ }^{76}$

- Filiberto Nantanni Madrigali à Cinque ${ }^{77}$

$[\ldots][115 r][\ldots]$

- Giovanni Mouton Messe di Musica ${ }^{78}$

- Gio: Pietro Luigi Messe in Musica ${ }^{79}$

- Giovanni Contino Musica ${ }^{80}$

- Il medesimo Madrigali à cinque ${ }^{81}$

- Gio: Domenico del Giovane Villanelle ${ }^{82}$

- Gio: Maria Tasso à due voci ${ }^{83}$

- Gio: Piero Luigi Madrigali à Quattro ${ }^{84}$

- Giovanni Naspo Madrigali à sei ${ }^{85}$

- Giaches de Ponte Canzone del Bembo ${ }^{86}$

- Giaches de Wert Madrigali à Quattro ${ }^{87}$

- Il medesimo madrigali a sei ${ }^{88}$

- Giuliano Tiburtino Ricercari ${ }^{89}$

[...] [119v] [...]

- Josquin Messe di Musica ${ }^{90}$

- Jangelo Mottetti ${ }^{91}$

- Il medesimo madrigali a due voci ${ }^{92}$

- Jacques Bues Canzoni Franzesi à sei ${ }^{93}$

- Jangelo Canzoni Franzesi à dua ${ }^{94}$

$[\ldots][124 \mathrm{v}][\ldots]$

- Musica nelle nozze del Gran Duca Cosimo 95

- Matteo Rampollini Canzone del Petrarca in Musica ${ }^{96}$

- Morales Mottetti à tre ${ }^{97}$

- Moresche in Musica ${ }^{98}$

- Madrigali Franzesi di diversi ${ }^{99}$

[...] [126r] [...]

- Niccolo Gombert Mottetti à Cinque ${ }^{100}$

- Niccolo Dorati Madrigali à Cinque ${ }^{101}$

$[\ldots][127 r][\ldots]$

- Orlando Di Lasso Mottetti à Cinque ${ }^{102}$

- Orlando Di Lasso Mottetti à Cinque ${ }^{103}$

- Il medesimo Madrigali à quattro terzo libro ${ }^{104}$

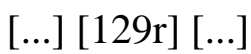

- Pietro della Rue - Pietro Rosselli [129v] Pippelore - Pietro Moulin Messe in Musica ${ }^{105}$ 
- Piero di Montignon Madrigali Franzesi ${ }^{106}$

[...] [135r] [...]

- Verdelott Madrigali à Quattro ${ }^{107}$

- Il medesimo Madrigali à sei ${ }^{108}$

- Vincentio Ruffo Madrigali à cinque ${ }^{109}$

There are about sixty titles in total, roughly half the number recorded in the 1591 inventory among the 'music books of various type'. Notably and for reasons unknown, only the printed editions, not the manuscripts, are included in the 1628 list. Only in about ten cases we can precisely identify the edition based on the scant details offered by the compiler of the inventory. ${ }^{110}$ What we seem to be able to deduce from this list, however, is that the collections did not contain any music composed after Gaddi's death, which occurred, as noted, in 1591. The number of unidentified editions is nevertheless high; this last assumption must therefore be accepted with the benefit of the doubt. In any case, taking the collection as a whole, the editions may be divided into three groups: 1) sacred music - masses and motets - nearly all by Franco-Flemish composers of the first half of the sixteenth century (Brumel, Gombert, Gero, Josquin, Mouton, Willaert, etc.); 2) profane music-chansons, madrigals, and instrumental music - by Franco-French composers active for the most part in the first half of the sixteenth century (Arcadelt, Buus, de Ponte, de Wert, Nasco, Verdelot, etc.); 3) madrigals and instrumental music by Italian composers active throughout the same century (the most sizable group). In terms of the first two groups, this repertory was admittedly obsolete by the late sixteenth century and most likely (at least in the case of sacred music) was not performed in Gaddi's house in that period. In this respect, Niccolò fulfilled an important role as a 'preserver' of music publications of the first half of the century. In many cases, in fact, we have a very low survival rate of the editions mentioned in the inventory. It is important to stress that in the context of late 
sixteenth-century Florence, in the cradle of the Camerata fiorentina and of the new music (as we will see below), this collection is quite retrospective and it is interesting for what it does not have. The simplicity of a lot of the music, and also the presence of the two-voice collections - which have often been assumed to be quasi pedagogical in nature - is interesting because it confirms what we know from other sources regarding the persistence of older music for decades (often in reprints). Probably the collection was meant for amateurs who might have not been comfortable with the later Marenzio, for example, or the later Wert. ${ }^{111}$

A number of post-1628 documents, already known in many cases but not carefully analyzed for this purpose, can nonetheless contribute substantially to our knowledge of the fate of this collection as well as our ability to identify some of the surviving works and obtain further details on the instruments as well as printed and manuscript scores.

\section{Musical instruments, and published and manuscript music books in later documents, as well as some surviving examples}

The musical instruments and books remained in the palazzo for a long time. The instruments were seen and described in brief by Giovanni Targioni Tozzetti (171283), prefect of the Biblioteca Magliabechiana from 1739 to mid-century. ${ }^{112}$ His visit was prompted by the desire of the then owner, Gaspero Gaddi (1712-96), to sell parts of the collection.

As in 1628 , so now the instruments were still housed on the first floor of the gallery's wing, as underscored by Targioni Tozzetti's words: 'I believe that the Gentleman [Niccolò] must have really enjoyed music because on top of each shelf that holds manuscript codices are a great many musical instruments, stringed and bowed, such 
as violins and basses, but of various make and very different from the ones used these days'. ${ }^{113}$ During the visit, Targioni Tozzetti was guided by Gaspero, who apparently told him what was known about the family collection at the time. What is important to emphasize here, is that he clearly believed that the collection of instruments went back to Niccolò Gaddi and his musical interests. This was clearly the same group of objects mentioned in the inventories. Given their location on top of the shelves of the library, we may assume that they had not been used for a long time, probably not since they had been moved to this room at some point between 1591 and 1628 . From this same source we can infer that the wooden organ commissioned by Niccolò Gaddi had never actually been finished:

'Sig.re Gaspero also had me look in his closet at a large stack of pipes meant for a huge organ, each made of four slender rectangular slats, similar to those of an organ that stood in the Jesuit Church of S. Giovannino. This organ too, he told me, had been conceived and begun by Cav. Niccolò Gaddi, who, in his will, had ordered his heirs to have it finished and accessible to the public, in our metropolis.' 114

Unfortunately, given the present lack of information, it is impossible to identify any of the instruments that may have survived.

As for the library, in 1755 Gaspero Gaddi sold 1100 manuscripts and 1451 printed books, among which were 211 incunabula, to the Grand-Duke Francesco I of Lorraine. ${ }^{115}$ Negotiations were conducted by the same Targioni Tozzetti, who, in the documentation generated at the time by the sale, also explained how the collection had come into being, and mentioned some members of the family who, in his opinion, had been responsible for its expansion (see Appendix). Although the document does not refer specifically to manuscript and printed music books, it is interesting in what it reveals about the wealth of the collection, on the one hand, and the diverse roles played by the various members of the Gaddi family in the formation of this extraordinary collection over the course of nearly four centuries, on the other. 
Targioni Tozzetti clearly based himself on what Gaspare Gaddi had told him about the history of the collections. Notable is the primary role again assigned to Niccolò Gaddi, viewed as responsible for 'significant expansions'.

The volumes acquired by the Grand-Duke Francesco I were subdivided among the Archivio delle Riformagioni, the Biblioteca Laurenziana, and the Biblioteca Magliabechiana. The books in print all ended up in the last of these, as did the music manuscripts. ${ }^{116}$ The inventories of the sale, again compiled by Targioni Tozzetti, refer only to a pair of printed editions and some music manuscripts, which, after being merged in the Magliabechiana, appear today in the catalogs of the Biblioteca Nazionale Centrale in Florence.

Purchased from among the print editions that can be traced back to the inventory of 1628 were: 'Pratica Musice Franchini Gafori Mediolani opera, et imprensa Joannis Petri de Lomatio per Guillermum Lignene Rohomagensem, 1497 in fol. vol. un. C.o', ${ }^{117}$ and 'Rerum Musicalium Joannis Petri Loisij, Liber primus. Impressum Rome apud Valerium Doricum, et Aloijsium fratres 15[6]4. In fol. vol. un. M.o'. ${ }^{118}$ Among the manuscripts, absent from the inventory but certainly coming to the Magliabechiana from the same collection, was a total of five codices that contained musical compositions, of which one has been missing since $1883 .{ }^{119}$ These too are now preserved in the Biblioteca Nazionale Centrale in Florence: Ms II.I.285 (olim Magl.XIX.56; Gaddi 1112), Lamentazioni di Geremia, bearing the date 22 February 1559; ${ }^{120}$ Ms Magl.XIX.57 (olim Gaddi 1103), François Roussel's Chansons, which can be dated to the mid-sixteenth century; ${ }^{121}$ Ms II.I.232 (olim Magl.XIX.58; Gaddi 1113), Mottetti a quattro, cinque e sei voci, with compositions by Agricola, Isaac, Josquin, Obrecht, Compère, Brumel, Elzear Genet, Antoine de Longueval, Jean Mouton, Jean Richafort, Pierre de la Rue, Eustachius de Monte, Regali Gallus, Ninot 
le Petit, datable to 1520; ${ }^{122}$ Ms Banco rari 229 (olim Magl.XIX.59; Gaddi 1024), Chansons a tre e quattro voci (illuminated codex), with works by Martini, Isaac, Agricola, Busnoys, Caron, Compère, Josquin, Obrecht, and others, datable to the 1490s; ${ }^{123}$ Ms Magl.XXXVI.28 (olim Gaddi 44), Laudi spirituali, missing since 1883. ${ }^{124}$ There were clearly other sales after the one in 1755 since some manuscripts with numbers above 1110 have entered the Magliabechiana. ${ }^{125}$

The fate of the other printed and manuscript music books is not known. The fact that there were so few of them in the 1755 sale is certainly surprising. It could be that the rest of the collection was sold in an earlier (more likely) or later block to Francesco I or to other buyers, or else later dispersed in various sales. It is also possible that the instruments and musical partbooks were subject to a cumulative sale. ${ }^{126}$ In any case, though the evidence at our disposable is still scant, it offers important additional bits of information to what has already emerged from sixteenth and seventeenth-century documents. The information obtained thus far makes it possible to frame Niccolò di Sinibaldo Gaddi's collections and musical patronage within the context in which he lived and worked.

\section{Niccolò Gaddi's collections and musical patronage in Florence in the second half of the sixteenth century and their possible ties to Rome}

Although it could not measure up to the Medici holdings, which already amounted to around 65 musical instruments in 1564, and was to grow to a total of about 200 in the course of the next 60 years, ${ }^{127}$ Niccolò Gaddi's collection was without doubt a considerable one within the context of Florence in the second half of the sixteenth century. An interesting comparison can be made with the one belonging to the composer and patron, Jacopo Corsi (1561-1602), who often hosted performances in 
his palazzo on via Tornabuoni, famous among which was that of Ottavio Rinuccini's Dafne in $1598 .{ }^{128}$ In 1603 this collection consisted of around one hundred items, above all keyboard and wind, but also bowed and plucked instruments. ${ }^{129}$ The Medici and Corsi collections, however, were utterly exceptional cases, while references to other collections of musical instruments in Florence in this period are infrequent. As for the wooden organ commissioned by Gaddi himself, this was the sort of instrument that enjoyed a certain success in the city in the final decades of the century. ${ }^{130}$ Mentioned by Adriano Banchieri in his Conclusioni del suono dell'organo (1609), ${ }^{131}$ it was defined as a 'concert' instrument by Emilio De' Cavalieri, who, proposing its use for intermezzi and pastoral tales, and thus had a certain number of its kind built between 1588 and 1600, particularly for the Medici. ${ }^{132}$ In the Rappresentazione di anima e corpo (1600), the same De' Cavalieri advised that others use them, ${ }^{133}$ just as Monteverdi had in his $\operatorname{Orfeo}(1609$, but performed for the first time in Mantua in 1607), which required the use of two wooden organs either individually or as a pair, placed one on the right and one on the left of the stage. ${ }^{134}$ Three wooden organs were used during the festivities held on the occasion of the nuptials of Ferdinando de' Medici and Christina of Lorraine. Incidentally, we may recall that on this occasion the same Gaddi played a key role in planning and organizing the various events.

The performance of the comedy La Pellegrina, commissioned by Ferdinando from Girolamo Bargagli and staged by members of Siena's Academia degli Intronati in the theater of the Uffizi, ${ }^{135}$ had six intermezzi - composed by Antonio Archilei, Cristofano Malvezzi and Luca Marenzio, among others - that called for the following instrumental ensemble: two violins, two violas da braccio, four violas da gamba, a violone, four lutes, a harp, a cittern, a pandoura, four trombones, a flute (unspecified), 
a recorder, a cornetto, two guitars, a chitarrone, a regal, a tambourine, in addition to precisely three wooden organs, for a total of around thirty instruments, played in small groups in various combinations. ${ }^{136}$ It is particularly important to stress that Gaddi's collection copied this ensemble in nearly mirror fashion. We can thus surmise that Niccolò at least had in mind, and perhaps even did, organize similar types of performances in his casa dell'orto. As we have seen, his musical library also contained a fair number of printed editions of contemporary madrigals and instrumental music, which we may believe were performed by the group of instruments on view in the stanza de' suoni.

Another important circle in Florence to which Gaddi's collections and patronage can be linked in the final quarter of the sixteenth century is, of course, the so-called Camerata de' Bardi, a coterie of humanists, poets and musicians who were accustomed to meeting at the residence of Giovanni de' Bardi on via de' Benci. ${ }^{137}$ One objective of this group was to revive ancient Greek drama, and, in the second half of the 1570s, its members therefore engaged in frequent discussions on ancient ancient music. ${ }^{138}$ Commemorated by Giulio Caccini in his Euridice (1600), ${ }^{139}$ the Camerata counted among its members, not only Bardi and Caccini, but also Vincenzo Galilei and Piero Strozzi, the musicians Emilio de' Cavalieri, Cristoforo Malvezzi and Alessandro Striggio, and the men of letters Ottavio Rinuccini, Gabriello Chiabrera, and Giovanni Battista Strozzi.

It was precisely to one of the members of the Camerata, Piero di Matteo Strozzi (1551-1614), ${ }^{140}$ that Niccolò Gaddi bequeathed 'the new harpsichord that had been made ${ }^{141}$ - a gift, thus directed at a person described as an 'amateur composer' and "nobleman, who played an important intellectual role in fostering the "new music" in Florence during the late $16^{\text {th }}$ century'. ${ }^{142}$ Piero Strozzi was selected as one of the two 
interlocutors, along with Bardi himself, in the Dialogo della musica antica, et della moderna published by Vincenzo Galilei in $1581 .{ }^{143} \mathrm{He}$ was a distant relative of Gaddi's second wife, and we may thus presume that he frequented the casa dell'orto and was involved in musical activities of some sort. ${ }^{144}$ Moreover, as noted earlier, Gaddi owned quite a number of music books by composers associated with the Camerata de' Bardi, such as Alessandro Striggio, for example. ${ }^{145}$ Further proof of musical patronage that went beyond the interest of a mere collector lies in the dedication of Il primo libro delli madrigali, a quattro voci, di Francesco Rossello, nuovamente da lui composti et dati in luce, published in Rome by Valerio Dorico in 1565 , to 'Cav. Gaddi' ${ }^{146}$ Surely this was a collection of works offered to Niccolò di Sinibaldo Gaddi, who had indeed been appointed a Knight of the Order of San Jacopo della Spada in 1552, and was often referred to by this title. ${ }^{147}$ A composer most likely of French origin, François Roussel (c.1510-post1577), worked for a long time in Rome as maestro di cappella in various churches of the city and in the service of Alessandro Farnese, among others. He was active in Lyon during the 1550s, and was at the service of Florentine patrons transplanted to France. ${ }^{148}$ It was precisely through his connection with the musical milieu of Lyon that Roussel developed relations with Niccolò Gaddi's uncle, the cardinal of the same name (1490-1552) already mentioned above, who resided in the city for extended periods and later returned to Florence for health reasons in $1550 .{ }^{149}$ Indeed in an article published in 1977, Greer Garden claimed that the composer himself had sought the patronage of the younger nephew. ${ }^{150}$

The only known surviving example - solely the tenor's part - of the edition dedicated to Gaddi was once in the Florentine collection of Baron Horace de Landau; sold at auction by Sotheby's in 1949, unfortunately its present location is not known. ${ }^{151} \mathrm{~A}$ 
copy of this edition existed in Gaddi's collection. ${ }^{152}$ Among the manuscripts acquired by Targioni Tozzetti for the Biblioteca Magliabechiana, is a tiny volume of François Roussel's chansons - only the alto part - that Greer Garden claimed had belonged to Niccolò di Sinibaldo Gaddi. ${ }^{153}$ Although it is true that the composer worked in Lyon for some time, as Garden emphasized, ${ }^{154}$ we cannot forget that he was active for a long time in Rome, and was in the service of Cardinal Farnese (1520-89), as already noted. The sole surviving currently known case of one of the print editions presumably owned by Gaddi, namely, that of the masses composed by de la Rue, Roselli, Pipelare and Moulu, and published in Rome by Giacomo Giunta in $1522,{ }^{155}$ is preserved today in the Biblioteca Nazionale Vittorio Emanuele III in Naples. ${ }^{156}$ On the title pages of all four of its parts (C, A, T, B) appears Alessandro Farnese's note of ownership, certainly dating later than his appointment as Vice-Chancellor of the Church upon the death of his predecessor, Ippolito de' Medici in $1535 .{ }^{157}$ At present it is impossible to determine securely whether this is the copy that belonged to Gaddi, ${ }^{158}$ but it should be noted that several of the print editions and at least a couple of Gaddi's five surviving manuscripts, II.I.285 and II.I.232, ${ }^{159}$ can be associated with the milieu of the Roman curia in the mid-sixteenth century. We must not forget that two of Niccolò Gaddi's paternal uncles - Niccolò and Giovanni - were elected to the rank of Cardinal, as was his first cousin Taddeo and a distant relative Girolamo. I believe that part of the works in print mentioned in the inventory of 1628 and the manuscripts listed in the sale of 1755, particularly those of sacred and secular music by Franco-Flemish or Italian composers of the first half of the sixteenth century, can be traced to one or more of these members of the family. Although we can be sure of Giovanni Gaddi's interest in music along with his possession of a well-stocked library, ${ }^{160}$ and can at least assume Niccolò di Taddeo's 
ties with musicians, ${ }^{161}$ we have no concrete information about Taddeo and Girolamo Gaddi save the testimony of Targioni Tozzetti, who attributed to the latter a purchase of manuscript codices in Rome (see Appendix). Although this is deemed a trustworthy source, further confirmation and in-depth analysis - which, however, fall beyond the scope of this study - are definitely needed.

\section{Conclusions}

Thanks to the documents of 1591, Giovan Antonio Dosio's drawings for the casa dell'orto, the inventory of 1628 and the eighteenth-century testimony of Giovanni Targioni Tozzetti, the studies conducted thus far have enabled us to reconstruct in large part the substance of Niccolò di Sinibaldo Gaddi's collection of intruments and his library of music books, as well as to trace the later fate of some of their surviving contents. They have also allowed us to recognize, though hypothetically, the contributions made to the collection in the form of printed and manuscript musical partbooks by some members of the family. We have proposed several hypotheses regarding the function and usage of the musical instruments, and finally, have inserted Gaddi's collections and musical patronage into the context in which he lived and operated.

To sum up the results of this study, it is possible, first of all, to affirm that Niccolò di Sinibaldo commissioned the construction of musical instruments - at least the wooden organ (unfortunately never completed) situated in the ground-floor gallery of the casa dell'orto to 'Annibale da Milano' (possibly Ferrante de' Rossi) and 'Lorenzo di Dom.co legnaiuolo', and the harpsichord later bequeathed to Piero di Matteo Strozzi. Secondly, it can be said for certain that the same building housed a rich collection of musical instruments well suited for performing the contemporary repertory, and 
possibly acquired by the same Niccolò. With all probability he himself also contributed to the expansion of the music library, adding to what was already there attributable to one or more of the family's cardinals - works by madrigalists of his time (Striggio, Donato, De Monte, Portinaro, Nantermi, Contino, Da Nola, Tasso, De Wert, Dorati, Lasso, Ruffo, etc.). Gaddi was also able to establish ties with musicians (among whom certainly was François Roussel) and prominent figures in the Florentine music world (in primis Piero di Matteo Strozzi). But above all, by outfitting the stanza de' suoni with a display of musical instruments and creating a special room for the library, Gaddi pursued the important objective of endorsing his family's legacy and making it available to the public, just as he did with the rest of his collection, all of which was housed together in a single building, the casa dell'orto. Heir to the patrimony and 'uses' of his own family's patronage of culture, he not only increased, endorsed, and opened the collections and the building containing them to the public through his conduct, but also was able to perpetuate the name of his house - which would have died out after his demise - and bound it for a long time with the prestige and distinction that derived from possessing so many objects of such quality. To these, the Pitti descendents, who assumed the Gaddi name, also added their own collections, thus creating over time one of the largest private collections in Florence. The figure of Niccolò di Sinibaldo Gaddi thus emerges not only as that of one of the major art patrons and collectors of Florence in the second half of the sixteenth century, but also as a crucial trait d'union for his own family, capable of directing its patrimony and the prestige that both the generations before and after him derived from it. The latter, thanks to the initiative of other important personages, were able to conserve and preserve the collection until the second half of the eighteenth century, when the sales and process of dispersion commenced. 
Missing today from what was listed in the inventories of 1591 and 1628 is a substantial number of music manuscripts and nearly all the printed partbooks, not to mention the musical instruments. The recovery and physical examination of other surviving objects could make a significant contribution to the study of collections and patronage of the various members of the Gaddi family. 


\section{Appendix}

ASFi, Consiglio di Reggenza, envelope 555, fasc. 725.

[205v] La Biblioteca Gaddiana, quantunque sia stata messa insieme da privati Gentiluomini, nientedimeno è considerabilissima, e piuttosto Principesca che no', se si riguarda il numero dei Codici manoscritti che la compongono, ascendente in tutto a n.o 1110, cioè 629 in Foglio, 400 in quarto e 81 in ottavo, se si considera la loro bellezza essendovene circa 250 scritti in cartapecora, e moltissimi con vaghe miniature, iniziali dorate, e se finalmente si riflette sulla rarità ed importanza delle materie contenute nei medesimi.

Poichè si trovano in essi quasi tutte le più belle opere degli antichi scrittori più rinomati, si Greci, che Latini, e quasi tutte le Opere di quegli Uomini dottissimi, che in Italia nei Secoli XIII, XIV, e XV richiamarono in vita Le quasi estinte Scienze, e belle Lettere e sottraendole dalle tenebre della Barbarie, le posero in luminosa vista. [...] [206r] Il primo che si pose à fare questa raccolta fu Angelo Gaddi Pittore, figliolo di Taddeo, e Nipote di Gaddo Gaddi anco essi celebri Pittori, che fiorì nella fine del 1300.

Egli trovandosi ricchissimo alla morte del Padre, non volle più fare il pittore, e datosi ad una vita tranquilla si applicò allo Studio dell'erudizione, e per suo uso raccolse molti de' più antichi, e bei Codici in ciascheduno dei quali si vede scritto di Sua mano Liber mei Angeli Taddei de Gaddis et Amicorum.

È notabile, che esso si pose à raccogliere manoscritti avanti à Cosimo, e Lorenzo dei Medici, e perciò non dee recare maraviglia se tra questi molti ve ne Sono, che non cedono in bellezza, ed importanza ai Medicei Laurenziani.

[206v] Il Cardinal Girolamo Gaddi accrebbe questa raccolta con molti bellissimi manoscritti, che acquistò in Roma, e notabilmente ancora l'aumentò Francesco Gaddi stato uno dei Segretari della Repubblica Fiorentina.

Questi due soggetti eruditi, e di buon gusto, a competenza dei Medici comprarono dai Letterati Greci scampati dall'Eccidio di Costantinopoli molti illustri manoscritti, in lingua Greca, e molte loro traduzioni dal Greco in Latino.

Non trascurarono però di raccogliere anco le Opere dei più belli ingegni Italiani dei loro tempi; anzi Si vede che uno di loro acquistò ò tutta, ò in parte la Libreria di Coluccio Salutati, e quella di Luca Bernardino da S. Gemignano, e di un certo Bernardo Puccini, nelle quali erano testi preziosi.

Ad essi pure si devono i tanti altri bei Codici di Opere di Leonardo Aretino, del Poggio, del Panormita \& poichè la bella serie dei Danti, e suoi Espositori fu quasi tutta raccolta da Agnolo Gaddi.

Grandi furono gli accrescimenti, che fece alla stessa Biblioteca l'Erudito, e ricco

Cav.re Niccolò Gaddi ultimo della Sua Famiglia, il quale poi la lasciò Fidecommissa à un Ramo della famiglia Pitti.

Il Sen.re Jacopo Pitti primo Erede vi aggiunse i Manoscritti, che erano proprii di [207r] sua casa, raccolti in gran parte da Buonaccorso, et altri Letterati Pitti.

E finalmente molti ve nè aggiunse Jacopo Pitti Gaddi iuniore celebre letterato del Secolo passato.

Alle premure di essi valentuomini si deve oltre questa bella raccolta di manoscritti anco un'altra non meno considerabile di Libri stampati dentro al 1400 con altri più moderni. 


\section{Image captions}

Fig. 1. Lodovico Buti, Portrait of Niccolò Gaddi, 1596, oil on canvas, 67.5 x 51.5 cm, Accademia delle Arti e del Disegno, Florence.

Fig. 2. Stefano Bonsignori, Bonaventura Billocardi, Nova pulcherrimae civitatis Florentinae topographia accuratissime delineata, Florence: Girolamo Franceschi, 1594 (inv. 1584, with revisions), etching on paper, 125 x $138 \mathrm{~cm}$, in J. Del Badia, Pianta topografica della città di Firenze di don Stefano Bonsignori dell'anno 1584 (Florence, 1899). Detail of the area around the Piazza Madonna degli Aldobrandini. A: casa grande or casa degli sporti; B: casa dell'orto.

Fig. 3. Giovan Antonio Dosio, Plan for the ground floor of Niccolò Gaddi's casa dell'orto, pen, ink, and brown wash over pen lines, 434 x 774 mm, GDSU, 623 A. 1: andito della casa piccola; 2: scrittoio a terreno; 3 : camera terrena che riesce in su la strada; 4: andito che riesce in su la loggia; 5: loggetta sull'orto; 6: camera in su l'orto; 7: spezieria; 8: stanza de' suoni; 9: corticina; 10: orto; 11: galleria su l'orto. Names of locations drawn from the 1591 inventory.

Fig. 4. Giovan Antonio Dosio, Plan for the façade of the galleria of Niccolò Gaddi's casa dell'orto, pen, ink, and brown wash over pen lines, 467 x 745 mm, GDSU, 4131 A. 


\section{Address for correspondence}

University of St Andrews, School of Art History, 79 North Street, St Andrews KY16 9AL, UK.

lm93@st-andrews.ac.uk

\section{Acknowledgments}

This study is part of a larger project entitled 'In the House of the Muses: Collection, Display, and Performance in Sixteenth-Century Italy', for which I received a Lila Wallace-Reader's Digest Fellowship at Villa I Tatti, The Harvard University Center for Italian Renaissance Studies in 2014-15. I would like to thank this institution and the employees of the Florentine archives and libraries who assisted me during my work. My gratitude extends to Lucio Biasiori, Bonnie Blackburn, Kathryn Bosi, Joseph Connors, Flora Dennis, Michele Magnabosco, Lia Markey, Brenda Preyer, Lorenzo Polizzotto, Maria Virginia Rolfo and Giovanni Zanovello for their advice and suggestions. I am also grateful to the anonymous reviewers for their feedback and recommendations.

The article has been translated from Italian by Irina Oryshkevich.

\section{Notes and references}

${ }^{1}$ For Niccolò Gaddi's biography, see the corresponding entry in Dizionario Biografico degli Italiani (Rome, 1960-) (henceforth DBI), vol. 51, pp. 164-5. On the portrait by Lodovico Buti (Fig. 1), see Firenze e la Toscana dei Medici nell'Europa del Cinquecento. Il primato del disegno (Florence, 1980), n. 140, pp. 91-2.

${ }^{2}$ For biographical profiles of members of the Gaddi family, see the corresponding entries in DBI, vol. 51. See also J. Gaddi, Trattato istorico della famiglia de' Gaddi (Padua, 1642). 
${ }^{3}$ For a general overview of Niccolò Gaddi's collections, see C. Acidini, 'Niccolò Gaddi collezionista e dilettante del Cinquecento', Paragone Arte XXXI/359-361 (1980), pp. 141-75. On the casa dell'orto, see E. Barletti, A. Morrogh, 'La 'casa dell'orto' di Niccolò Gaddi', in E. Barletti (ed.), Giovan Antonio Dosio (Florence, 2011), pp. 467-505.

${ }^{4}$ A significant portion of the currently known documents had been published in the two articles mentioned in the previous note.

${ }^{5}$ On Niccolò Gaddi's collection of drawings, see, among others, Acidini, op. cit. (note 3). Andrew Morrogh is currently working on the volumes of Vasari's Libro de' disegni in Gaddi's possession. See his upcoming publications on the subject. On architectural commissions, see, in addition to Acidini, op. cit. (note 3), the following essays published in Barletti, op. cit. (note 3): A. Morrogh, 'La cappella Gaddi nella chiesa di Santa Maria Novella', pp. 299-325; A. Morrogh, 'Il vecchio palazzo dei Gaddi', pp. 457-65; C. Acidini, 'Tre madrigali e alcune osservazioni sulla cappella Gaddi nella chiesa di Santa Maria Novella', pp. 327-43; Barletti, Morrogh, op. cit. (note 3). Gaddi himself was a draughtsman and designer, as testified by documents of the period and a drawing by his own hand for the Niccolini Chapel in Santa Croce preserved in the Gabinetto Disegni e Stampe degli Uffizi, Florence (henceforth GDSU), 4340 A. On Gaddi as an amateur architect, see esp. Acidini, op. cit. (note 3). On his drawing for the Niccolini Chapel, see Acidini, op. cit. (note 3), p. 147 and fig. 141; A. Morrogh, Disegni di architetti fiorentini, 1540-1640: Catalogo (Florence, 1985), n. 52, pp. 111-2; R. Spinelli, 'La cappella Niccolini nella basilica francescana di Santa Croce', in Barletti, op. cit. (note 3), pp. 345-77, esp. pp. 355-6.

${ }^{6}$ R. Gualterotti, B. De' Rossi, Descrizione del regale apparato fatto in Firenze per le nozze del Serenissimo Gran Duca di Toscana e di Madama Cristina di Loreno (Mantua, 1589); R. Gualterotti, Descrizione dell'apparato, e degl'intermedi fatti per la commedia rappresentata in Firenze nelle nozze de' serenissimi Don Ferdinando Medici, e Madama Cristina di Loreno, Gran Duchi di Toscana (Florence, 1589); J. M. Saslow, The Medici Wedding of 1589: Florentine Festival as Theatrum Mundi (New Haven, 1996), esp. pp. 22-5; C. Pizzorusso, Firenze 1589: un modello ritrovato per gli apparati delle nozze di Ferdinando I De’ Medici e Cristina di Lorena (Florence, 2000). 
${ }^{7}$ On related themes albeit in different contexts, see D. Howard, L. Moretti (eds), The Music Room in Early Modern France and Italy: Sound, Space and Object (Oxford, 2012); L. Moretti, 'The function and use of musical sources at the Paduan 'court' of Alvise Cornaro in the first half of the Cinquecento', Journal of the Alamire Foundation 2 (2010), pp. 47-61; L. Moretti, 'L'immagine della musica nello "studio" del palazzo veronese di Mario Bevilacqua (1536-93)', Music in Art XL/1-2 (2015), pp. 285-96.

${ }^{8}$ Archivio di Stato, Florence (henceforth ASFi), Ospedale della SS. Trinità detto degli Incurabili, Testamenti e Donazioni, 1542 to 1576 , file 9, ins. 8, cc. $78 \mathrm{r}-84 \mathrm{r}$ (henceforth Inventario 1591). I would like to thank Lia Markey for drawing my attention to this document. Additional copies in ASFi, Spedale dei Convalescenti, 653, s.n, published in Acidini, op. cit. (note 3), pp. 153-64; Archivio Ricasoli Firidolfi, Florence (henceforth ARFFi), file 43, fasc. 10, ins. 13, published in Barletti, Morrogh, op. cit. (note 3), pp. 497-502.

${ }^{9}$ Inventario 1591, c. 79v: 'Nella stanza de' suoni: Dieci viole, sei liuti, una lira, un'arpa, due cetere, due pandore, un sordino, un gravicembalo, sei casse da tromboni con loro tromboni dentro, una cassa di quoio con sette flauti, un cornetto, due toppe grande di ferro per il cassone'.

${ }^{10}$ Inventario 1591, c. 80r: 'uno organo di legno in testa della Galleria non finito'. ${ }^{11}$ Inventario 1591, c. $84 \mathrm{r}$ : In the 'fourth room' above the galleria: 'Una libreria con più pezzi di libri in stampa et in penna di più sorte alla rinfusa, che sono numero mille quattrocento libri di più sorte' among which were 'libri cento trenta di musica di più sorte'.

${ }^{12}$ For a biographical profile of Giovanni Gaddi, see DBI, vol. 51, pp. 156-8.

${ }^{13}$ On the Gaddi palace in Rome, see M. Morresi, Jacopo Sansovino (Milan, 2000), pp. 50-65. In his life of Giovan Francesco Rustici, Giorgio Vasari reports on a theatrical performance organized by Giovanni Gaddi: ‘con l'aiuto di Jacopo Sansovino, d'Andrea del Sarto, e di Giovanfrancesco Rustici [Gaddi] rappresentò un Tantalo nell'inferno, che diede mangiare a tutti gli uomini della compagnia vestiti in abiti di diversi Dii, con tutto il rimanente della favola, e con molte capricciose invenzioni di giardini, paradisi, fuochi lavorati, et altre cose, che troppo, raccontandole, farebbono lunga la nostra storia'. G. Vasari, Le vite de' piu eccellenti pittori, scultori, e architettori (Florence, 1568), vol. 2, p. 607. See also A. M. 
Cummings, 'The Company of the Cazzuola and the Early Madrigal', Musica Disciplina 50 (1996), pp. 203-38, esp. pp. 203-9; T. Mozzati, Giovanfrancesco Rustici, le compagnie del paiuolo e della cazzuola: arte, letteratura, festa nell'età della maniera (Florence, 2008), with further references, above all on Giovanni Gaddi's membership in the so-called 'Compagnia della Cazzuola'.

${ }^{14}$ DBI, vol. 51, p. 157.

${ }^{15}$ DBI, vol. 51, pp. 161-4.

${ }^{16}$ See G. Garden, 'François Roussel: A Northern Musician in Sixteenth-Century Rome', Musica Disciplina 31 (1977), pp. 107-33, esp. p. 113.

${ }^{17}$ See B. Preyer, 'The Florentine casa', in M. Ajmar-Wollheim, F. Dennis (eds), At Home in Renaissance Italy (London, 2006), pp. 34-49, esp. pp. 38-9; Morrogh, op. cit. ['Il vecchio palazzo'] (note 5), with additional references.

${ }^{18}$ See Acidini, op. cit. (note 3); Morrogh, op. cit. ['Il vecchio palazzo'] (note 5); Barletti, Morrogh, op. cit. (note 3).

${ }^{19}$ ASFi, Ospedale della SS. Trinità detto degli Incurabili, Testamenti e Donazioni, 1542 to 1576 , file 9, ins. 8, cc. 70r-78r (henceforth Testamento 1591), published in part in Acidini, op. cit. (note 3), pp. 165-7. Another copy can be found in ARFFi, file 47, fasc. 4, published in Barletti, Morrogh, op. cit. (note 3), pp. 494-7.

${ }^{20}$ The same craftsmen were also charged with finishing the woodwork of a studiolo situtated in the 'hall' on the first floor. Testamento 1591, c. 76r: 'Voglio [...] quanto prima per il mio erede si faccia finire lo studiolo cominciato in detta casa [the casa dell'orto], et l'organo della Galleria secondo il disegno di m.ro Lorenzo et p. le sue mani, et d'Annibale da Milano'. Gaddi reserved a sum that the two craftsmen would receive once the job was done. Testamento 1591, c. 71v: 'A m.ro Lorenzo di Dom.co legnaiuolo quando haverà fornito lo studiuolo che mi lavora gli lascio fiorini cento, et quando harà fornito l'organo della Galleria fiorini cinquanta. A Annibale da Milano lascio fiorini cinquanta'. On Annibale and Ferrante de' Rossi, see esp. E. L. Kottick, A History of the Harpsichord, vol. 1 (Bloomington, 2003), pp. 94-5, with further references. I wish to thank Flora Dennis and one of the anonymous reviewers for their comments and suggestions on this point.

${ }^{21}$ Testamento 1591, c. 76r: 'A mad.a Maria Strozzi mia moglie lascio un gravicembolo coperto di panno verde'.

${ }^{22}$ DBI, vol. 51, p. 164. 
${ }^{23}$ Testamento 1591, c. 76v: 'A Piero di Matteo Strozzi lascio il gravicembolo nuovo, che si fabbrica, il quale sia fatto finire p. i mia heredi'.

${ }^{24}$ On Piero Strozzi, see esp. Edmond Strainchamps in S. Sadie, J. Tyrrell (eds), The New Grove Dictionary of Music and Musicians, 2nd ed., 29 vols (London \& New York, 2001) (henceforth NG), vol. 24, p. 610. On the kinship between Piero Strozzi and Maria Strozzi Gaddi, see P. Litta, Famiglie celebri italiane, 16 vols (Milan, 1839), vol. 9, pl. 19. The latter's place on the Litta family tree is unclear (according to the author himself), but nonetheless it seems possible to exclude close kinship.

${ }^{25}$ See Morrogh, op. cit. ['Il vecchio palazzo'] (note 5) for further details.

${ }^{26}$ Morrogh, op. cit. ['Il vecchio palazzo'] (note 5). On Giovan Antonio Dosio, see, in general, Barletti, op. cit. (note 3) for all further references.

${ }^{27}$ Reference to the date of acquisition can be found in Barletti, Morrogh, op. cit. (note 3), p. 483.

${ }^{28}$ Barletti, Morrogh, op. cit. (note 3), pp. 467-505. The garden, known as the 'paradiso dei Gaddi', was to become famous. See esp. Barletti, Morrogh, op. cit. (note 3), pp. 469-473, with further references.

${ }^{29}$ On the Gaddi Chapel in Santa Maria Novella, see esp. Morrogh, op. cit. [La cappella Gaddi] (note 5); Acidini, op. cit. (note 5). It was here that stood the tombs of Cardinals Niccolò (d. 1552) and Taddeo (d. 1561), the patron's uncle and first cousin respectively. Placed beneath the two sarcophagi were two inscriptions dedicated to another uncle, Giovanni, likewise a cardinal (d. 1542) and the father, Sinibaldo (d. 558). Filling the rest of the structure were the tombs of his first wife, Emilia Ridolfi (d. 1563) and two offspring, Sinibaldo (d. 1564) and Lucretia (d. 1569), both of whom died at a tender age.

${ }^{30}$ Inventario 1591.

${ }^{31}$ Testamento 1591, c. 77r: 'Voglio che le cose, che saranno nella casa dell'orto si mostrino p. i miei eredi a ogni richiesta loro a tutti i gentiluomini fiorentini o forestieri che dessidererano vederle amorevolmente et cortesemente'.

${ }^{32}$ S. Ammirato, Opuscoli, 3 vols (Florence, 1637-42), vol. 2, p. 506, published in part in Barletti, Morrogh, op. cit. (note 3), pp. 469-71: 'Nella Città venti braccia discosto dalla sua habitazione ha un'altra casa con horto, i quali luoghi tenuti da gran Cittadini per loro delizie son chiamati Casini. Nell'Orto sono semplici eccellentissimi e rarissimi [...]. Nell'una delle faccie di detto orto è una galleria lunga parecchie 
braccia, da ciascun lato della quale sono sopra i lor piedistalli poste nobilissime statue di marmo, e sopra le statue collocati quadri di pittura di buoni maestri [...] condotto che fui negli appartamenti di sopra rimasi confuso affatto, considerando quel che può fare l'amore, l'assiduità, e l'ingegno degli huomini [...] basterà dirle che questa è una Sala con due camere, e due studioli con altri studioletti piccoli, e con alcuna soffitta, piene di tanti ornamenti di marmi, di getti di bronzi, di dipinture con tanti riposti di cose antiche rarissime di arme, di misure, di pesi e d'altre particolarità'.

${ }^{33}$ On this subject, see esp. J. M. Musacchio, 'Objects and Identity. Antonio de' Medici and the Casino at San Marco in Florence', in J. J. Martin (ed.), The Renaissance World (New York \& London, 2007), pp. 481-500; L. Tice, 'Recreation and Retreat: Garden Casini in Late Sixteenth- and Early Seventeenth-Century Rome', PhD Dissertation, Graduate School-New Brunswick, Rutgers, The State University of New Jersey (2009); L. Tice, 'Inventories of Casini in Late Sixteenth- and Early Seventeenth-Century Rome', Journal of the History of Collections XXIII/2 (2011), pp. 315-31, for additional references.

${ }^{34}$ Ammirato's visit probably took place before work on the organ had begun, since there is no mention of it in the letter cited above. See note 32.

${ }^{35}$ Inventario 1591, cc. $79 \mathrm{v}-80 \mathrm{r}$.

${ }^{36}$ Inventario 1591 , c. 80 r.

${ }^{37}$ Inventario 1591 , c. 84 r.

${ }^{38}$ Inventario 1591 , c. $79 \mathrm{v}$.

39 The drawings have been published in Barletti, Morrogh, op. cit. (note 3).

${ }^{40}$ This observation is also apparently confirmed by Scipione Ammirato's aforementioned description. See note 32. The other plan of the ground floor published by Morrogh, drawing GDSU, $624 \mathrm{~A}$, seems to be a depiction of the state of the building before work on it began, or - what is less likely - an initial but later abandoned idea of the architect. Likewise shown in the drawing is a garden, which, in turn, was cropped in GDSU, 623 A. See Barletti, Morrogh, op. cit. (note 3), fig. 12 (GDSU, 624 A), p. 476, and fig. 14 (GDSU, 623 A), p. 478.

${ }^{41}$ On Pozzoserrato's painting, see, among others, E. Filippi, catalogue entry in G. Beltramini, H. Burns (eds), Andrea Palladio e la villa veneta (Venice, 2005), p. 389, with additional references. 
${ }^{42}$ On this topic, see in particular, F. Dennis, 'Music', in Ajmar-Wollheim, Dennis, op. cit. (note 17), pp. 228-43; the following articles in Howard, Moretti, op. cit. (note 7): F. Dennis, 'When is a Room a Music Room? Sounds, Spaces and Objects in Noncourtly Italian Interiors', pp. 37-49; L. Moretti, 'Spaces for Musical Performance in the d'Este Court in Ferrara (c.1440-1540)', pp. 213-36, with additional references. ${ }^{43}$ See esp. Barletti, Morrogh, op. cit. (note 3), p. 479.

44 Testamento 1591, c. 74v: 'che portasse il nome della famiglia de Gaddi, et quello usar in pubblico et in privato'. See also Barletti, Morrogh, op. cit. (note 3), p. 479. 45 Testamento 1591, c. 77v: 'Se i miei heredi vorranno liberare la casa dell'orto $\mathrm{p}$ abitarla possono fare una Galleria sopra quella, che vi è, et in essa collocare tutte le cose, che sono nelle stanze di detta casa'. Dosio's plan was probably only completed in part, judging from the comparison of this passage in the will and the drawn elevation of the gallery's wing (Fig. 4). On this question, however, see Barletti, Morrogh, op. cit. (note 3), pp. 483-94.

${ }^{46}$ ASFi, Notarile moderno, Protocolli, 10481, cc. 7r-151r, 11 February 1627 Florentine style (=11 February 1628 current style), unpublished (henceforth Inventario 1628). I would like to thank Brenda Preyer and Lorenzo Polizzotto for drawing my attention to this inventory.

${ }^{47}$ I am currently in the final stages of researching this inventory; further publications on various aspects of the document will follow.

${ }^{48}$ Inventario 1628, c. 8r: 'Nella sala della casa di Firenze dell'orto, dove habita detta signora Maria con li suoi signori figlioli', 'un gravicembalo coperto di cuoio con suoi piedi di noce'.

${ }^{49}$ Inventario 1628, c. 47r: 'Seconda stanza della galleria: un sordino coperto di quoio; [...] undici [ralini]; sei liuti; tre cetere; dua chitarre alla Spagnuola; un violino; un liutino; un [suono]; sei cassette di quoio dorate entrovi tromboni; una custodia di albero di un [suono]; una scatola entrovi trentacinque rocchetti di corde; [...] un flauto di osso nero con manicha d'argento'. It is impossible to identify the instrument listed as 'suono'. Presumably 'ralini' refer to viols. As will emerge below, the author of the inventory made similar errors when compiling the document, which presents several inaccuracies.

${ }^{50}$ Inventario 1628 , cc. $89 \mathrm{v}-135 \mathrm{v}$. From what can be understood, this was the same room in which musical instruments were kept at the time. 
${ }^{51}$ Jacques Arcadelt (c.1507-68) published five books of madrigals for four voices, all of which were reprinted numerous times. The first book in particular appeared in nearly forty re-editions between 1539 and 1654. See James Haar, Letitia Glozer in NG, vol. 1, pp. 843-8.

${ }^{52}$ Adrian Willaert (c.1490-1562) published various ricercari for three and four voices between 1540 and 1551, generally within collections of other composers. See Lewis Lockwood et alii in NG, vol. 27, pp. 389-400. In this case, it may have been one in the collection Fantasie, recercari, contrapunti a tre voci di M. Adriano et de altri autori appropriati per cantare et sonare d'ogni sorte di stromenti, published in 1551, 1559 and 1593. See Répertoire international des sources musicales, Series A/I (Munich, 1960-) (henceforth RISM), vol. 9, W1120-W1122, p. 226; H. M. Brown, Instrumental Music Printed Before 1600. A Bibliography (Cambridge, MA, 1965), $1551^{6}$, p. $131,1559^{8}$, p. $189,1593^{8}$, p. 392.

${ }^{53}$ Agostino Licino (fl. c.1545) is known solely for his two volumes of compositions for two voices: il Primo libro di duo cromatici, published in Venice by Antonio Gardano in 1545, and reprinted by Girolamo Scotto in 1586, and Il secondo libro di duo cromatici, published once again in Venezia by Antonio Gardano, in 1546. See Howard Mayer Brown, Naomi Joy Barker in NG, vol. 14, p. 655; RISM, vol. 5, L2342-L2344, p. 33. See also M. S. Lewis, Antonio Gardano, Venetian Music Printer, 1538-1569: A Descriptive Bibliography and Historical Study, 3 vols (New York, 1988-), vol. 1, n. 68, pp. 467-8, and n. 87, pp. 519-20.

${ }^{54}$ See note 52. Willaert published two editions of motets for four voices in Venice with Girolamo Scotto in 1539. Both collections were republished in 1545 by Antonio Gardano. See RISM, vol. 9, W1106-W1109, p. 225. These editions enjoyed wide circulation in the sixteenth century.

${ }^{55}$ See note 51.

${ }^{56}$ Unidentified edition.

${ }^{57}$ See note 51 . The specification 'second book' presupposes an earlier reference to a first. Various reprints exist of the second book, first published in Venice by Girolamo Scotto in 1539. See J. A. Bernstein, Music Printing in Renaissance Venice: The Scotto Press, 1539-1572 (New York, 1998), n. 1, pp. 223-4.

${ }^{58}$ Giovanni Animuccia (c.1500-69) published his Primo libro di madrigali a quatro a cinque et a sei voci in Venice with Antonio Gardano in 1547. See Lewis Lockwood in 
NG, vol. 1, p. 688; RISM, vol. 1, A1241, p. 73; E. Vogel, A. Einstein, Bibliography of Italian Secular Vocal Music Printed between the Years 1500-1700, 2 vols (Washington, D.C., 1945) (henceforth NV), vol. 1, n. 86, p. 59. See Lewis, op. cit. (note 53), vol. 1, n. 100, pp. 552-4.

${ }^{59}$ Girolamo Scotto published Alessandro Striggio's (c.1536-92) Il Cicalamento delle donne al bucato et la Caccia [...] a quattro cinque sei e sette voci, con il Gioco di primiera a cinque voci $[. .$.$] nuovamente agionto, in Venice in 1569. It was$ republished by Scotto's heirs in 1584. See Iain Fenlon in NG, vol. 24, pp. 575-9; RISM, vol. 8, S6960-S6961, p. 284; NV, vol. 2, nos 2655-2656, pp. 1652-3. An interesting detail is the fact that the document mentions only the third of the compositions in the collection. This may have been a separate isolated edition - of which there is no record in the literature - or an indication of the edition's owner's special interest in this particular composition. Most probably, the compiler of the inventory reported what he had found written on the volume's cover. ${ }^{60}$ Anton Francesco Doni (1513-74) published his Dialogo della musica in Venice, with Girolamo Scotto, in 1544. See James Haar in NG, vol. 7, pp. 467-8; RISM, vol. 2, D3419, p. 434; NV, vol. 1, n. 857, pp. 560-1. See Bernstein, op. cit. (note 57), n. 40, pp. 303-7.

${ }^{61}$ See note 59. Alessandro Striggio published five collections of madrigals for five voices and two for six voices; these were frequently reissued. See NV, vol. 2, nos 2656bis-2687, pp. 1653-70.

${ }^{62}$ This could be Armonia di scelti authori a sei voci sopra altra perfettissima armonia di bellezze d'una gentil donna senese, published in Venice by the heirs of Girolamo Scotto in 1586. See F. Lesure, Recueils Imprimés; XVIe-XVIIe Siécles: Liste Chronologique, Repertoire International Des Sources Musicales (Munich, 1960) (henceforth RISM Recueils), $1586^{7}$, p. 332. The collection - dedicated to Giovanni de' Bardi - contains compositions by Cristoforo Malvezzi and Alessandro Striggio, among others.

${ }^{63}$ Antoine Brumel (also known as Brummel, Brommel, Brunel, Brunello) (c.1460c.1513), was a highly prolific composer of sacred music, particularly of masses. See Barton Hudson in NG, vol. 4, pp. 494-8. This may be the famous edition of the Liber quindecim missarum electarum quae per excellentissimos musicos compositae 
fuerunt, published in Rome by Andrea Antico in 1516. The first composition in the collection is, in fact, by Antoine Brumel. See RISM Recueils, 1516¹ , p. 97.

${ }^{64}$ Baldassarre Donato (c.1529-1603) published Il primo libro di madrigali a cinque et a sei voci con tre dialoghi a sette in Venice with Antonio Gardano in 1553; it was later republished again in Venice by Plinio Pietrasanta in 1557 and once again by Gardano in 1560. See Anu Ahola in NG, vol. 7, pp. 458-9; RISM, vol. 2, D3411D3413; NV, vol. 1, nos 853-855, pp. 558-9. See also Lewis, op. cit. (note 53), vol. 2 , n. 181 , pp. 259-62.

${ }^{65}$ Further data are not provided. Lupacchino published three books of madrigals for four and five voices, which also appeared in many editions aside from the collection mentioned below, note 83. See Thomas W. Bridges in NG, vol. 15, pp. 316-7. ${ }^{66}$ Cipriano de Rore (c.1515-65) published two books of madrigals for four voices. The first, in particular, reappeared in numerous editions. See Jessie Ann Owens in NG, vol. 21, pp. 667-77.

${ }^{67}$ See previous note. De Rore published five collections of madrigals for five voices, which went through numerous editions.

${ }^{68}$ Costanzo Festa (c.1485-1545) published various collections of madrigals for three voices with works by various composers, some of which were republished. See James Haar in NG, vol. 8, pp. 728-31.

${ }^{69}$ This might be the collection Fantasie, Recercari e Contrapunti a tre voci, published in Venice by Antonio Gardano in 1551. See RISM Recueils, $1551^{16}$, p. 181. The edition contains compositions by Cipriano de Rore, in addition those by Adrian Willaert, among others. It appeared in at least two editions, with some variation. ${ }^{70}$ Henri Schaffen (b. early $16^{\text {th }} \mathrm{c}$.) published Li suoi madrigali a quatro voce a notte negre in Venice with Girolamo Scotto in 1549. See Don Harrán in NG, vol. 22, p. 434; RISM, vol. 7, S1247, p. 360; NV, vol. 2, n. 2587, pp. 1603-4. See Bernstein, op. cit. (note 57), n. 82, pp. 382-4.

${ }^{71}$ Unidentified author.

${ }^{72}$ Francesco Corteccia (1502-71) had his Responsoria omnia quintae ac sextae feriae sabbatique maioris hebdomade paribus vocibus published in Venice by Antonio Gardano's heirs in 1570. See Frank A. D’Accone in NG, vol. 6, pp. 507-9; RISM, vol. 2, C4153, p. 232. 
73 The editio princeps of the Practica musicae by Franchino Gaffurio (1451-1522) was published in Milan by Guillaume Le Signerre in 1496. See the Indice Generale degli Incunaboli delle Biblioteche d'Italia, 6 vols (Rome, 1943-81), vol. 3, n. 4112, p. 3. Two other editions followed, the first reprinted twice: in Brescia in 1497, 1502 and 1508, and in Venice in 1512. The work was widely disseminated. See Bonnie J. Blackburn in NG, vol. 9, pp. 410-4. See also note 117, with additional references. ${ }^{74}$ François Roussel (c.1510-post 1577) published Il primo libro delli madrigali, a quattro voci, in Rome with Valerio Dorico in 1565. See Greer Garden, Richard Sherr in NG, vol. 21, p. 810; NV, vol. 2, n. 2432, pp. 1506-7 with a list of 33 madrigals in the collection. See also Garden, op. cit. (note 16), pp. 128-30; S. Cusick, Valerio Dorico: Music Printer in Sixteenth-Century Rome (Ann Arbor, MI, 1981), n. 43, pp. 213-5. See also notes 148-152, for further details.

${ }^{75}$ Philippe de Monte (1521-1603) published at least nine books of madrigals for six voices. See Robert Lindell, Brian R. Mann in NG, vol. 17, pp. 16-21.

${ }^{76}$ Francesco Portinaro (c.1520-post 1577) published four books of madrigals for five voices. See Maria Archetto in NG, vol. 20, p. 189.

${ }^{77}$ Filiberto Nantermi (d. 1605), member of a family of musicians, is known today solely for having published a madrigal in Michelangelo Nantermi's Primo libro de madrigali a cinque voci, Venice: Ricciardo Amadino, 1609. See John Whenham in NG, vol. 17, pp. 613-4; RISM, vol. 6, N34, p. 291; NV, vol. 2, n. 1995, p. 1226. This may be the same edition though it seems rather strange that the name of Filiberto not Michelangelo, who wrote 18 out of the 21 madrigals published in the collection, appears on the list. Aside from one of Filiberto's madrigals, the edition contains two madrigals by Orazio, another member of the family. More likely, this is an unknown edition containing madrigals only by Filiberto. Indeed, a book of madrigals for five voices by 'Filiberto Lanterni' is mentioned in the inventory of books in the library of the heirs of Filippo Giunti in 1604, and this may be the edition listed in the inventory. See O. Mischiati, Indici, cataloghi e avvisi degli editori e librai musicali italiani dal 1591 al 1798 (Florence, 1984), p. 111.

${ }^{78}$ Jean Mouton (pre1459-1522) composed about fifteen masses, published in two editions by Ottaviano Petrucci in 1515. See Howard Mayer Brown, Thomas G. MacCracken in NG, vol. 17, pp. 239-51; RISM, vol. 6, M4015, p. 42; S. Boorman, Ottaviano Petrucci: Catalogue Raisonné (New York, 2006), n. 60, pp. 794-801. 
${ }^{79}$ Giovanni Pierluigi da Palestrina (c.1525-94) published an outstanding number of masses in various editions, which saw numerous reprints. See Lewis Lockwood, Noel O’ Regan, Jessie Ann Owens in NG, vol. 18, pp. 937-57. See also note 118 for further details.

${ }^{80}$ Giovanni Contino (c.1513-74) published various editions of sacred and secular music. See Iain Fenlon in NG, vol. 6, pp. 344-5.

${ }^{81}$ See previous note. Contino published Il primo libro de' madrigali a cinque voci in 1560 in Venice with Girolamo Scotto. See RISM, vol. 2, C3544, p. 197; NV, vol. 1, n. 606, pp. 402-3. See also Bernstein, op. cit. (note 57), n. 179, pp. 542-4. Another book of madrigals for five voices by this composer is now apparently lost. ${ }^{82}$ Giovanni Domenico da Nola (known as Giovanni Domenico del Giovane) (c.1510/20-92) published Il primo libro delle villanelle alla napolitana a tre e quattro voci in Venice in 1567 . The edition was reissued in 1569 by Claudio da Correggio (who probably published the first one as well) and in 1570 by Girolamo Scotto. See Donna G. Cardamone in NG, vol. 18, pp. 17-8; RISM, vol. 6, N778-N780, p. 338; NV, vol. 1, nos 1254-1256, pp. 790-1. On the 1570 edition, see Bernstein, op. cit. (note 57), n. 349, pp. 817-8. In this case it is possible to note that the name 'del Giovane', by which the composer was known, does not appear in the editions. This is a detail that the inventory taker working several decades later would most likely not have known. As we can tell from the way in which he cited the authors on the list, he was no expert. It is once again believed that the person who drafted the document copied what was written on the cover. See note 59.

${ }^{83}$ Today Giovanni Maria Tasso is known solely for having written - together with Bernardino Lupacchino - Il primo libro a note negre a due voci, published in Venice by Antonio Gardano in 1559. An earlier edition, probably going back to the1540s, is mentioned in Antonfrancesco Doni's La libraria (1550), but unfortunatey seems to be lost today. The collection was republished in numerous editions until 1701. See NG, vol. 25, p. 117; RISM Recueils, $1559^{24}$, p. 229; NV, vol. 2, n. 1522, p. 954 (Scotto edition, 1565). Nontheless it is impossible to identify the edition. Strangely enough, the list contains Tasso's name despite the fact that the primary author of the collection was Lupacchino. See remarks in the previous note.

${ }^{84}$ See note 79. Palestrina published two books of madrigals for four voices, of which the first in particular - initially published in Rome in 1555 - was reissued multiple 
times. See RISM, vol. 6, P752-P760, P763, p. 403; NV, vol. 2, nos 2090-2099, pp. 1285-9.

${ }^{85}$ Jan Nasco (c.1510-61) published Le Canzon et Madrigali a sei voci con uno dialogo a sette in Venice with Antonio Gardano in 1557, an edition reprinted by the same in 1562. See George Nugent in NG, vol. 17, pp. 646-7; RISM, vol. 6, N82-N83; NV, vol. 2, nos 2002-2003, pp. 1229-30.

${ }^{86}$ Giaches de Ponte (c.1510-post 1546) published his Cinquanta stanze del Bembo in Venice with Antonio Gardano in 1545. The collection was reprinted four times by 1567. See Jeffrey Dean in NG, vol. 20, pp. 95-6; RISM, vol. 7, P5073-P5076, p. 8; NV, vol. 1, nos 882-886, pp. 579-81.

${ }^{87}$ Giaches de Wert (1535-96) published his Primo libro de' madrigali a quattro voci in Venice with Girolamo Scotto in 1561. The collection was reissued numerous times. See Iain Fenlon in NG, vol. 27, pp. 296-302; RISM, vol. 9, W865-W870, p. 209; NV, vol. 2, nos 2962-2966, pp. 1848-50.

${ }^{88}$ See previous note. Giaches de Wert's madrigals for six voices appeared in various editions, along with others for four, five and seven voices.

${ }^{89}$ Giuliano Tiburtino (c.1510-69) published his Fantasie e recerchari a tre voci, accomodate da cantare et sonare per ogni instrumento in Venice with Girolamo Scotto in 1549. See James Haar in NG, vol. 25, p. 462; RISM, vol. 8, T774, p. 354; Brown, op. cit. (note 52), 15497 , pp. 117-8. See J. Haar, 'The 'Fantasie et recerchari' of Giuliano Tiburtino', The Musical Quarterly LIX/2 (1973), pp. 223-38; Bernstein, op. cit. (note 57), n. 95, pp. 404-6.

${ }^{90}$ Josquin des Prez (c.1450-1521) published numerous volumes of masses, which too were reprinted. See Patrick Macey et alii in NG, vol. 13, pp. 220-66.

${ }^{91}$ Jhan Gero (fl. 1540-55) published two books of motets for five voices in 1555 in Venice with Girolamo Scotto. See James Haar in NG, vol. 9, pp. 745-6; RISM, vol. 3, G1625, p. 219. See also Bernstein, op. cit. (note 57), nos 140-1, pp. 475-8.

${ }^{92}$ See previous note. In 1541 Gero published Il primo libro de madrigali italiani, et canzon francese, a due voci in Venice with Antonio Gardano. The edition was republished and reissued many times. See RISM, vol. 3, G1626-G1646, p. 219. ${ }^{93}$ Jacques Buus (c.1500-65) published Il primo libro di canzoni francese a sei voci in Venice with Antonio Gardano in 1543. See H. Colin Slim in NG, vol. 4, p. 695; RISM, vol. 1, B5194, p. 462. See also Lewis, op. cit. (note 53), n. 40, pp. 369-72. 
${ }^{94}$ See note 91 . This may have been Il primo libro de madrigali italiani et canzoni francese a due voci published initially in Venice by Antonio Gardano in 1541 and subsequently reissued approximately twenty times by 1687. See RISM, vol. 3, G1626-G1645, p. 219; NV, vol. 1, nos 1123-1145, pp. 726-37.

${ }^{95}$ Most likely this is Musiche fatte nelle nozze dello illustrissimo duca di Firenze il signor Cosimo de Medici et della illustrissima consorte sua mad. Leonora da Tolleto, Venice: Antonio Gardano 1539. See RISM Recueils, 1539²5, p. 127 (compositions by Corteccia, Festa, Masaconi, Moschini, Rampollini).

${ }^{96}$ Matteo Rampollini (1497-1553) published Il primo libro de la musica [...] sopra di alcune canzoni del divin poeta $m$. Francesco Petrarca in Lyon with Jacques

Moderne, probably in 1560. See Andrew C. Minor in NG, vol. 20, pp. 814-5; RISM, vol. 7, R215, p. 94. On the date of the edition, see esp. S. F. Pogue, Jacques Moderne: Lyons Music Printer of the Sixteenth Century (Geneva, 1969), n. 65, pp. 213-8; F. A.

D'Accone, 'Matteo Rampollini and his Petrarchan Canzone Cycles', Musica

Disciplina 27 (1973), pp. 65-106; F. Dobbins, Music in Renaissance Lyons (Oxford \& New York, 1992).

${ }^{97}$ Cristóbal de Morales (c.1500-53) published motets for three voices in miscellaneous collections, e.g. in RISM Recueils, $1543^{6}$, p. $140 ; 1549^{13}-1549^{14}$, p. 168. See Robert Stevenson, Alejandro Planchart in NG, vol. 17, pp. 85-91. ${ }^{98}$ The title is too generic to permit the issue's identification.

${ }^{99}$ These probably were chansons. The title is too generic to permit identification. ${ }^{100}$ Nicolas Gombert (c.1495-c.1560) published two books of motets for five voices in 1539 and 1541, which were later reissued several times. See George Nugent, Eric Jas in NG, vol. 10, pp. 118-24; RISM, vol. 3, G2981-G2986, pp. 294-5.

${ }^{101}$ Niccolò Dorati (c.1513-93) published four books of madrigals for five voices between 1549 and 1567. See Gabriella Biagi Ravenni in NG, vol. 7, p. 505; RISM, vol. 2, D3422-D3425, p. 434; NV, vol. 1, nos 858-861, pp. 561-5.

102 Orlando di Lasso (c.1530-94) published many motets for five voices in various collections. See James Haar in NG, vol. 14, pp. 295-322.

${ }^{103}$ Written twice. See previous note.

${ }^{104}$ See note 102. The editions of madrigals for four voices were likewise different. 105 This might be the Missarum decem a clarissimi musicis compositarum ac dum antea exceptis tribus aeditarum. Liber primus published in Rome by Giacomo Giunta 
in 1522 . The collection contains masses by various composers, including Pierre de la Rue, Petrus Roselli, Mattheaus Pipelare and Pierre Moulu. See RISM Recueils, 1522, p. 101. See also notes $155-157$ for further details.

${ }^{106}$ Unidentified author.

${ }^{107}$ Philippe Verdelot (c.1480-pre1555) published at least three books of madrigals for four voices. The first two in particular were reissued numerous times. See H. Colin Slim, Stefano La Via in NG, vol. 26, pp. 427-34; RISM, vol. 9, V1218-V1222, V1226, V1228-V1238, pp. 74-6; NV, vol. 2, nos 2866-2883, pp. 1785-95.

${ }^{108}$ See previous note. Three collections of Verdelot's madrigals for six voices were published between 1541 and 1561. See NV, vol. 2, nos 2890-2892. See also, for the first two editions, Lewis, op. cit. (note 53), n. 25, pp. 296-300; n. 97, pp. 542-5. ${ }^{109}$ Between 1553 and 1556, Vincenzo Ruffo (c.1508-87) published different collections of madrigals for five voices; these were reprinted numerous times before 1562. See Lewis Lockwood, Alessandra Amati-Camperi in NG, vol. 21, pp. 874-5; RISM, vol. 7, R3071-R3084; NV, vol. 2, nos 2482-2489, 2491-2494, pp. 1536-44. ${ }^{110}$ See notes 58, 60, 62, 70, 72, 81, 89, 93, 96, 105.

${ }^{111}$ I wish to thank one of the anonymous reviewers for her/his remarks on this point. ${ }^{112}$ For a bibliographical profile of Giovanni Targioni Tozzetti, see C. Cipriani, A. Scarpellini, Un contributo alla mineralogia settecentesca. La collezione di Giovanni Targioni Tozzetti (Florence, 2007).

${ }^{113}$ Biblioteca Nazionale Centrale, Florence, (henceforth BNCFi), Targioni Tozzetti 189, vol. 9, c. 353, published in Barletti, Morrogh, op. cit. (note 3), p. 503: 'Io credo che esso Cav.re [Niccolò] si dilettasse anche molto di musica, poiché sopr'agli scaffali dove stavano i codici manoscritti, vi era un numero grande d'instrumenti musicali da corda e arco, a guisa di violini e bassi, ma di fatture assai varie, e molto diversi da quelli che si praticano oggigiorno'.

${ }^{114}$ Barletti, Morrogh, op. cit. (note 3), p. 503: 'Mi fece anche vedere il Sig.re Gaspero, nella sua guardaroba, una gran massa di canne per un organo grandissimo, fatte ciascheduna di quattro assicine sottili rettangole, sull'andare di quelle d'un organo che era nella Chiesa di S. Giovannino dei Gesuiti. Anche quest'organo, mi disse che era stato ideato e principiato dal Cav. Niccolò Gaddi, il quale nel testamento ordinò agli eredi di farlo terminare, e collocare al pubblico, nella nostra metropoli' 115 Acidini, op. cit. (note 3), p. 168, n. 15. 
${ }^{116}$ ASFi, Consiglio di Reggenza, envelope 555 (henceforth Reggenza 555), fasc. 724 (for manuscripts) and 725 (for printed material). The archive called 'delle Riformagioni' received the codices on the subject of Florentine history, correspondence among ambassadors and rulers, and committee records; the Biblioteca Laurenziana received the originals and copies of Greek and Latin classics, Latin translations of Greek works by famous fifteenth-century Greek experts, and literary works of the thirteenth, fourteenth and fifteenth centuries; the Biblioteca Magliabechiana received the collection of manuscripts on the history and government of Florence, Tuscany, and other regions, on civil, criminal, and canonical law, politics, theology, Holy Scriptures mathematics, philosophy, medicine, chemistry, natural history, arithmetic and painting, erudite writings, poetry, literature, miscellanea and Latin grammar, etc. All the printed books ended up in the last of these three institutions. Reggenza 555, fasc. 724, c. 184. Later some of the manuscript codices were moved from the Magliabechiana to the Laurenziana. See BNCFi, [M. Morena Schiavotti], Codici Gaddiani. Tavole di concordanza delle segnature dei codici trasferiti dalla Magliabechiana alla Laurenziana il 13/07/1783.

${ }^{117}$ Reggenza 555, fasc. 725, n. 214, c. 103v. Ora BNCFi, Magl.C.3.27. This is the 'Franchino Giapporo Pratica della Musica Latina' in the inventory of 1628 . See note 73. Although the current binding is modern, traces of an earlier leather cover exist. There are a few corrections in ink on the inside. On the flyleaf appears a note in pencil that reproduces a no longer extant label. The copy has a cartouche with the acknowledgement 'Francisci Caesaris Augusti munificentia' on the inside of the rear cover, much like those coming from the Gaddi library, as noted in A. M. Cummings, 'A Florentine Sacred Repertory from the Medici Restoration', Acta Musicologica LV/2 (1983), pp. 267-332, at p. 270.

${ }^{118}$ Reggenza 555, fasc. 725, n. 415, c. 114v. Most likely this is Giovanni Pierluigi da Palestrina's Missarum Liber Primus, published in Rome by Valerio and Luigi Dorico in 1554, now in the BNCFi, Mus. Ant. 1, listed in the inventory of 1628 as 'Gio: Pietro Luigi Messe in Musica'. See note 79. On this edition, see RISM, vol. 6, P655, pp. 396-7; Cusick, op. cit. (note 74), n. 26, pp. 185-6. Parchment binding restored in the modern period. On the spine is a rather damaged note in ink, repeated on the rear flyleaf in pencil: XIX MUS. [L.]OIS.1554. Small cartouche glued to the rear cover: 'Praenestini/Jo. G/Missarum Liber 1. 1554'. No mark on the inside. This copy too has 
a cartouche with the acknowledgement 'Francisci Caesaris Augusti munificentia' on the inside of the front cover. See previous note.

${ }^{119}$ Cummings, op. cit. (note 117), pp. 270-1.

${ }^{120}$ B. Becherini, Catalogo dei manoscritti musicali della Biblioteca Nazionale di Firenze (Kassel, 1959), n. 25, pp. 18-9. Mentioned in BNCFi, Magl.X.96, Catalogo dei Manoscritti della Libreria Gaddiana, 1783 (henceforth Catalogo 1783), c. 81v. See also Cummings, op. cit. (note 117), p. 277.

${ }^{121}$ Reggenza 555, fasc. 724, n. 1103, c. 90r. Becherini, op. cit. (note 120), n. 26, p. 19. Mentioned in Catalogo 1783, c. 80v. Discussed in F. Roussel, Opera Omnia, ed. Greer Garden, 5 vols (Neuhausen-Stuttgart, 1980-82), vol. 5, pp. IX-X. 122 Becherini, op. cit. (note 120), n. 27, pp. 21-2. Mentioned in Catalogo 1783, c. 81v. See Cummings, op. cit. (note 117), p. 268: 'The collection contains a repertory of sixty-five motets, two Mass-ordinary movements and the Summa Passionis of Antoine de Longueval, forming an especially rich and substantial cross-section of the international repertory from Josquin's time, and including seventeen of his motets, more than any other central manuscript source known to us.' The scholar links this codex to Leo X and Florentine and Roman circles, and assumes a Medician or in any case Florentine provenance of a private nature, in view of the non-exclusively liturgical nature of the collecion and the lack of references to institutional settings. Perhaps it initially belonged to the Medici. See Cummings, op. cit. (note 117), p. 293. ${ }^{123}$ Reggenza 555, fasc. 724, n. 1024, c. 86r. Becherini, op. cit. (note 120), n. 28, pp. 22-9. Mentioned in Catalogo 1783, c. 73v. A modern edition has been published in $\mathrm{H}$. M. Brown (ed.), A Florentine Chansonnier from the Time of Lorenzo the Magnificent: Florence, Biblioteca Nazionale Centrale, MS Banco Rari 229, 2 vols (Chicago, 1983).

${ }^{124}$ Reggenza 555, fasc. 724, n. 44, c. 6r. Becherini, op. cit. (note 120), n. 81, pp. 8990. Mentioned in Catalogo 1783, c. 3v.

${ }^{125}$ As pointed out in Cummings, op. cit. (nota 117), p. 271: 'A later inventory of Gaddi manuscripts in the Magliabechiana, dated 1783 (BNCFi, Magl.X.96), documents stages of acquisition subsequent to 1755 and lists manuscripts with numbers as high as 1156; it records the presence of manuscript 232 in the Magliabechiana at that time'. All the codices with the exception of II.I.232, display a cartouche with the acknowledgement 'Francisci Caesaris Augusti Munificentia', 
which refers to their purchase by the Grand Duke Francesco I of Lorraine, as in the case of the just mentioned editions of Gaffurio and Palestrina.

${ }^{126}$ I am currently carrying out research that could help identify surviving objects. I will report possible discoveries in future contributions.

${ }^{127}$ See, in particular, P. Gargiulo, 'Strumenti musicali alla corte medicea: nuovi documenti e sconosciuti inventari (1553-1609)', Note d'archivio per la storia musicale n.s. 3 (1985), pp. 55-71. See also W. Kirkendale, The Court Musicians in Florence during the Principate of the Medici. With a Reconstruction of the Artistic Establishment (Florence, 1993); G. Rossi Rognoni (ed.), Galleria dell'Accademia: The Conservatorio 'Luigi Cherubini' Collection: Bowed Stringed Instruments and Bows (Livorno, 2009).

${ }^{128}$ T. Carter, 'Music and Patronage in Late Sixteenth-Century Florence: The Case of Jacopo Corsi (1561-1602)', I Tatti Studies in the Italian Renaissance 1 (1985), pp. 57104; T. Carter, 'Non Occorre Nominare Tanti Musici: Private Patronage and Public Ceremony in Late Sixteenth-Century Florence', I Tatti Studies in the Italian Renaissance 4 (1991), pp. 89-104; D. Pegazzano, Committenza e collezionismo nel Cinquecento. La famiglia Corsi a Firenze tra musica e scultura (Florence, 2010). ${ }^{129}$ See Pegazzano, op. cit. (note 128), pp. 57-9 with a transcription of the inventory. ${ }^{130}$ See esp. P. P. Donati, 'Emilio dei Cavalieri: un organologo del Cinquecento', Informazione organistica XIV/1-3 (2002), pp. 185-231; P. P. Donati, 'Il ruolo dell'organo di legno in una fonte di primo seicento', Informazione organistica XX/1 (2008), pp. 41-62; G. Montanari, 'Gli organi di legno della Guardaroba Medicea nel XVII secolo', Informazione organistica XX/1 (2008), pp. 63-103.

${ }^{131}$ A. Banchieri, Conclusioni nel suono dell'organo (Bologna, 1609), pp. 14-5.

132 On this subject in particular, see Donati, op. cit. ['Emilio dei Cavalieri'] (note 130).

${ }^{133}$ E. De' Cavalieri, Rappresentatione di anima, et di corpo (Rome, 1600), 'Ai lettori', s.n. See also Donati, op. cit. ['Emilio dei Cavalieri’] (note 130), p. 197. ${ }^{134}$ C. Monteverdi, L'Orfeo (Venice, 1609), s.n.

${ }^{135}$ G. Bargagli, La Pellegrina (Siena, 1589). See, in addition to Saslow, op. cit. (note 6), H. M. Brown, Sixteenth-century instrumentation: the music for the Florentine intermedii (Rome, 1973); N. Treadwell, Music and Wonder at the Medici Court: The 
1589 Interludes for La Pellegrina (Bloomington, 2008), with additional

bibliographical details.

136 The ensemble used during the intermedi of La Pellegrina can be extrapolated from Intermedii et concerti fatti per la commedia rappresentata in Firenze nelle nozze del Serenissimo Don Ferdinando Medici, e Madama Christina Di Loreno, Gran Duchi di Toscana (Venice, 1591), from the ninth section in particular, in which the names of the players and details of the performance are listed in addition to the instruments. I wish to thank one of the anonymous reviewers for the correct interpretation for 'Cembalino adornato di sonagli d'argento', here translated with 'tambourine'. ${ }^{137}$ Within the vast bibliography on the subject, see above all C. Palisca, Humanism in Italian Renaissance Musical Thought (New Haven \& London, 1985); C. Palisca, The Florentine Camerata: Documentary Studies and Translations (New Haven \& London, 1989); Kirkendale, op. cit. (note 127); and most recently E. Abramov-van Rijk, Singing Dante: The Literary Origins of Cinquecento Monody (Burlington, 2015), with additional references. On the Palazzo Bardi alle Grazie see the list corresponding to the online data bank: 'Repertorio delle architetture civili di Firenze' ed. Claudio Paolini, with numerous bibliographical references. From what is known, the gatherings and musical performances took place in the salon on the first floor on the corner of via dei Vagellai. Iconographic and ornamental traces remain in the room despite its heavy renovation.

${ }^{138}$ Palisca, op. cit. [The Florentine Camerata] (note 137), p. 5.

${ }^{139}$ G. Caccini, Euridice (Florence, 1600), with a dedicatory letter addressed to Giovanni de' Bardi dated to 20 December 1600. See Palisca, op. cit. [The Florentine Camerata] (note 137), p. 3.

${ }^{140}$ See note 24.

${ }^{141}$ See note 23.

${ }^{142}$ Edmond Strainchamps in NG, vol. 24, p. 610.

${ }^{143}$ V. Galilei, Dialogo della musica antica, et della moderna (Florence, 1581). See also Claude V. Palisca in NG, vol. 9, pp. 436-9, with additional references.

${ }^{144}$ See note 24.

${ }^{145}$ See notes 59 and 61.

${ }^{146}$ See note 74.

${ }^{147}$ DBI, vol. 51, pp. 164-5. 
${ }^{148}$ See Greer Garden, Richard Sherr in NG, vol. 21, p. 810; Garden, op. cit. (note 16), pp. 110-4. See also P. Hurtubise, 'Une vie de palais: la cour du cardinal Alexandre Farnèse vers 1563', Renaissance and Reformation n. s. 16 (1992), pp. 37-54.

${ }^{149}$ On Niccolò di Taddeo Gaddi see esp. DBI, vol. 51, pp. 161-4.

${ }^{150}$ Garden, op. cit. (note 16), p. 113.

${ }^{151}$ Information provided in Garden, op. cit. (note 16), p. 128. See also NV, vol. 2, n. 2432, p. 1507.

${ }^{152}$ See note 74 . Based on presently known data, it is impossible to securely determine whether the copy belonging to Gaddi is the same one that was registered in the Landau collection.

${ }^{153}$ Roussel, op. cit. (note 120), vol. 5, p. X.

${ }^{154}$ See notes 34 and 35 .

155 See note 105 .

${ }^{156}$ Biblioteca Nazionale Vittorio Emanuele III, Naples, S.Q. 27. L 40-43.

${ }^{157}$ The note of ownership, which appears on all four parts (C, A, T, B), states: 'Del. Rev.mo Far. Vicecanc.' For a bibliographical profile of Alessandro Farnese, see DBI, vol. 45 , pp. 52-70.

${ }^{158}$ Roussel's links with members of the Gaddi family and the confirmed one with Alessandro Farnese make this fairly plausible.

${ }^{159}$ See notes 120 and 122 .

${ }^{160}$ See notes $12-14$.

${ }^{161}$ See notes 15-16. 